\title{
Customer Loyalty of Islamic Banks
}

\author{
Pramono Hari Adi ${ }^{1}$ \\ ${ }^{1}$ Jenderal Soedirman University, Purwokerto, Indonesia
}

\begin{abstract}
The highly rapid growth of sharia commercial banks have required them to compete in obtaining and retaining customers. Therefore, it is important to look carefully at the position of their brands within the industry. Among the measures to see how strong the position of a brand in the market is the level of customers' brand loyalty. There are five levels of brand loyalty, each of which indicates particular marketing challenge to be addressed. Those levels - from least loyal to most loyal - include switcher, habitual buyer, satisfied buyer, liking the brand, and committed buyer. Using questionnaire to collect primary data from 100 respondents, the results indicate that the highest brand loyalty to Islamic banks has been at the level of satisfied buyer and liking the brand, indicating that consumer loyalty to the Islamic banks has not been perfect. Loyalty needs to be improved towards the committed buyer.
\end{abstract}

Keywords: Brand, Customer Loyalty, Islamic Bank

\section{INTRODUCTION}

The Government of Indonesia through Bank Indonesia has established a policy to develop a dual (conventional and Islamic) banking system. Since then, number of sharia commercial banks has been growing very rapidly in Indonesia. By the end of 2013 there have been 11 Islamic banks, 24 sharia business units, and 160 sharia people loan banks (Bank Indonesia, 2013). This development cannot be separated from the economic crisis in 2008 leading to the assumed inability of conventional economic system to develop the economy and the search for an alternative economic system which is considered more appropriate.

Noting the number of existing banks, Islamic banks are required to compete in creating and maintaining customers, not only with the conventional banking but also with other Islamic banks. Therefore, various marketing efforts should be made to introduce the products and the brand of Islamic banking institution to the community. Facing the competition, it is important to look carefully at the position of their brands within the industry. Among the measures to see how strong the position of a brand in the market is the level of customers' brand loyalty (Aaker, 1996).

Because there have been many Islamic banks with diverse and innovative products, it cannot be well predicted that the two major players (Bank Muamalat Indonesia and Bank Syariah Mandiri) in the Indonesian Islamic banking market today are continuously able to maintain their position as the most powerful brands

\footnotetext{
* Corresponding author. Email address: hariadipramono@yahoo.com
} 
in the market (Karim Counsultant, 2009). The level of consumer loyalty to Islamic banking services will continue to change along with the increasing competition.

\section{LITERATURE STUDY}

The existence of Islamic banks in Indonesia has been driven by the desire of the Indonesian people (especially the Muslim community) who believe that interest is usury. Usury means addition. In linguistics, usury means to grow and expand (Saeed, 1996). Antonio (1999) mentions that technically, usury means making additional principal or capital unfairly. For religious reasons, there have been customers who are loyal to sharia banking; however, there have been others who access services from sharia as well as conventional banking services.

Brand loyalty measures customer attachment to a brand. This measure provides an overview of the likelihood of a customer to switch to another product, especially if the brand is experiencing a change, either in relation to price or other attributes. A customer who is very loyal to one brand will not easily switch their purchases to other brands, no matter what happens with the brand. When customer loyalty to a brand increases, the vulnerability of the customer group against competitors' threat and attack can be reduced. Thus, the role of brand loyalty is a core indicator of brand equity, which is clearly related to sales opportunities, thus guarantee of the company's profit in the future. Loyal customers in general will continue to purchase the brand even though they have many alternative brands that offer superior productc characteristics. Having many customers of a product in this category means that the brand has a strong brand equity. On the contrary, unfaithful customers, at the time they make a purchase of the brand generally do not base on their interest in the product, price and convenience of use or various other attributes offered by other alternative brands. When most customers of a brand fall within this category, it means that brand equity is weak.

Brand loyalty of the customers is a strategic asset. When it is properly managed and exploited, it will potentially provide values in some forms, which in turn gives a positive value for the customer and for the company. The company also has to keep creating and maintaining brand loyalty in various ways, such as by treating customers with decent, establishing a close relationship with customers, managing customer satisfaction, creating switching costs, and providing extra services (Aaker, 1997).

There are several levels of brand loyalty, each of which indicates particular marketing challenge to be addressed. The levels of brand loyalty include the following (Rangkuti, 2002):

a. Switchers, are customers who are at the most basic level. The higher the frequency the customers switch to other brands, indicating whether buyers are loyal.Usually this type of customer buys products due to low price.

b. Habitual buyers, are those who are satisfied with the products or at least do not experience disappointment, so that they do not switch to other brands. 
c. Satisfied buyers, are customers who are satisfied but they have to bear the costs of transition, including time, money, and risk to switch to other brands.

d. Liking-the-brand customers are those who really like the brand. Their choice of a brand is based on associations, such as a symbol of the series of experiences in using the brand or an impression of high quality.

e. Commited buyers are those who take pride of using a brand. An actualization of brand loyalty is to recommend and promote the brand to others.

\section{RESEARCH METHODOLOGY}

This study is a survey research with primary data in the form of responses to questionnaires. It also collected data obtained from secondary sources. The population of this study are customers of Islamic banks in Purwokerto, the number of which is difficult to find out. With a confidence coefficient of 0.05 which is equal to 1.96 , and determination of error of $10 \%$, the minimum sample size is 96.04 and is rounded to 100 respondents. Respondents were selected purposively and were distributed on existing Islamic banks.

\section{Operational definition of brand loyalty}

Brand loyalty is a measure of customer attachment to a brand. This measure provides an overview of the likelihood that a customer switch to other brands, especially when the particular brand is experiencing a change in price or other attributes. Loyalty is an indicator of brand equity which is associated with future sales and earnings. Loyalty consists of five levels (from low to high): switcher, habitual buyer, satisfied buyer, liking the brand, and committed buyer.

\section{Data Analysis}

Brand loyalty was measured using five-point Likert scales (strongly agree, agree, neutral, disagree, and strongly disagree). Before testing the hypotheses, data obtained from the respondents were tested for validity to determine how accurate an instrument performs the function of measuring. After that, reliability testing was performed to determine the stability of the instrument. The next step is tabulation of data to determine the average value to classify the levels of customers' brand loyalty.

Switchers are customers who are sensitive to price changes. Therefore, those fall in this category give responses such as "often" or "always". From tabulated data, the average values were obtained. The result of the calculation was mapped into a range of scales that produce interval (Durianto et al, 2001):

$$
\text { Interval }=\frac{\text { highest value }- \text { lowest value }}{\text { number of class }}=\frac{5-4}{5}=0.8
$$

Once the interval is known, then a range of scales can be created to find out the average assessment of respondents to each element of differentiation and the extent of the variation. The scale ranges are as follows:

1.00 to $1.800=$ very bad

1.81 to $2.60=$ bad 
2.61 to $3.40=$ sufficient

3.41 to $4.20=$ good

4.21 to $5.00=$ very good

The measurement of habitual buyer was based on answers "agree" and "strongly agree" on the questionnaire. The calculation follows the stages of switcher. Satisfied buyers in this study are those whose responses are "satisfied" and "very satisfied ". The calculation follows the stages of switchers and habitual buyers. Being classified as liking-the-brand customers are those who provided responses of "like" and "love" with the calculation similar to that of switcher and habitual buyer. Committed buyer is the level of loyalty marketers desire most, because when customers have reached this level, there will be very small likelihood for them to switch. Committed buyers are those who responded "often" and "always".

\section{RESULTS \\ Description of Respondents}

There were 48 female and 52 male respondents participating in the study, which was almost balanced. This shows that the economic activity at the moment has not been dominated by any particular gender. The majority of respondents (99 people) are moslems; only one respondent was non moslem. Most respondents (56) hold bachelor degree, followed by high school graduates (21) and the rest were distributed into various levels of education. Most respondents (35) work as private employees, followed by students (27). The majority of respondents (35) earned less than IDR 1 million per month, 22 earned more than 4 million and the rest (33) between 1-4 million.

Among 100 respondents, 77 have accessed the services offered by Islamic banks, while the rest (23) have not been customers of Islamic banks. They know about Islamic banks from mass media, visit to the office of Islamic banks, as well as information sharing from other people. Most respondents (41) have been in contact with Islamic banks for more than 3 years, but those who became customers for less than one year were quite large (26). This phenomenon illustrates that loyal customers to Islamic banks were quite large and new customers also increased. The reasons for which respondents chose Islamic bank have been dominated by compliance with sharia (36), followed by usury avoidance (17) while the other reasons were distributed evenly in less significant numbers. Most respondents (75) are associated with Islamic banks to save money. Other activities such as deposits and current accounts is very small (1), and the rest (24) to get loan (24). There were 36 respondents of this study who were only dealing with Islamic banks; the rest (47) accessed the services of Islamic bank as well as conventional bank. The dominance of dual customers has reflected the limited services and types of products that Islamic banks offere. The respondents said that they still use conventional banks for salary and scholarships transfer and due to more complete facilities provided by conventional banks when compared with Islamic banks.

Brand Loyalty 
Brand loyalty consists of five levels: switcher, habitual buyer, satisfied buyer, liking-the-brand buyer, and committed buyer. The measurement of brand loyalty used a reference table in the form of loyalty scale ranges based on the respondents' average responses so that loyalty levels were positioned in the scale range (interval). Table 4.26 shows the scale range of brand loyalty.

Table 1 Scale Range of Brand Loyalty

\begin{tabular}{cc}
\hline Interval & Category \\
\hline $1.00-1.80$ & Very small \\
$1.81-2.60$ & Small \\
$2.61-3.40$ & Sufficient \\
$3.41-4.20$ & High \\
$4.21-5.00$ & Very high \\
\hline
\end{tabular}

The result of the calculation of the bank's brand loyalty indicates that the switchers are at a sufficient level, reflecting that teh number of Islamic banking customers who have a habit of switching to another bank is still quite large. The customers have a high sensitivity to switch to other banks for the reson of price benefit. In such circumstances, Islamic banks should work hard to be able to increase the level of switcher to higher level of loyalty.

Table 2 Comparison of Average Values of Loyalty Levels of Islamic Banks

\begin{tabular}{lccccc}
\hline \multicolumn{1}{c}{ Bank } & Switcher & $\begin{array}{c}\text { Habitual } \\
\text { Buyer }\end{array}$ & $\begin{array}{c}\text { Satisfed } \\
\text { Buyer }\end{array}$ & $\begin{array}{c}\text { Liking } \\
\text { The } \\
\text { Brand }\end{array}$ & $\begin{array}{c}\text { Committed } \\
\text { Buyer }\end{array}$ \\
\hline $\begin{array}{l}\text { Bank } \\
\text { Muamalat }\end{array}$ & 3.18 & 1.91 & 3.60 & 3.75 & 3.78 \\
$\begin{array}{l}\text { Bank Syariah } \\
\text { Mandiri }\end{array}$ & 3.92 & 1.83 & 3.42 & 3.50 & 2.83 \\
$\begin{array}{l}\text { BRI Syariah } \\
\text { BNI Syariah }\end{array}$ & 3.50 & 3.50 & 3.50 & 4.00 & 2.00 \\
\hline & 2.57 & 1.86 & 3.57 & 3.71 & 3.29 \\
\hline
\end{tabular}

Habitual buyers are small in scale (score of 2.275). Buyers who are at this level are those who are satisfied with the products, or at least they do not experience disappointment, so they do not switch to another brand. This shows that the consumers of Islamic banks who are satisfied and do not switch to another bank are still small.

Consumers belonging to the satisfied buyers, defined as those who are satisfied with the transition costs are at a high scale (3.5225). Consumers at this stage feel satisfied, but they have to bear the costs of transition, including time, money, and risk in making efforts to switch to other brands. These customers are usually referred to as loyal customers who feel the presence of a sacrifice if they turn to other brands. So consumers at this stage it is still possible to switch when a competitor offers a lower cost of transition. This condition is very likely to happen upon the very high degree of competition.

However, liking-the-brand customers are in a high scale (3.74). Their choice of a brand is based on an association, such as symbol of series of experiences in using the product or high quality impression. This illustrates that the number of liking-the-brand consumers have been significant. 
Consumers who take pride in using Islamic banks are still in suffcient scale (2.975). Therefore, there have not been a lot of consumers who actualize brand loyalty by recommending and promoting the brand to other people; the Islamic banks, therefore, still have to foster promotional efforts.

\section{CONCLUSION AND RECOMMENDATION}

The highest brand loyalty to Islamic banks has been at the level of satisfied buyers and liking the brand, indicating that consumer loyalty to the Islamic banks has not been perfect. Loyalty needs to be improved towards the committed buyer. Overall, respondents who have reached the level of committed buyer were limited, so that the Islamic banking industry should continue to foster public awareness of Islamic banks to use services through outreach programs and well-managed and sustainable promotion. Although in the sufficient category, consumers being classified as switcher are still quite large in number, so it needs special attention in order to retain them not to move to other banks.

\section{References}

Aaker, D. (1996). Measuring Brand Equity Across Products and Markets. California Management Review, 38, 102-20.

Antonio, M.S. (1999). Bank Syari'ah: Wacana Ulama dan Cendekiawan. Bank Indonesia dan Tazkia Institue. Jakarta: STEI Tazkia.

Bank Indonesia dan CBR Universitas Andalas. (2006). Identifikasi Faktor Penentu Keputusan Konsumen dalam Memilih Jasa Perbankan antara Bank Syari'ah dengan Bank Konvensional di wilayah Sumatera Barat. Jakarta: Bank Indonesia.

Bank Indonesia dan LP Institut Pertanian Bogor. (2000). Potensi, Sikap dan Perilaku Masyarakat terhadap Bank Syari'ah di wilayah Jawa Barat. Bogor: Lembaga Penelitian IPB.

Bank Indonesia dan Pusat Penelitian Kajian Pembangunan Lembaga Penelitian Universitas Diponegoro Semarang. (2000). Penelitian Potensi, Preferensi dan Perilaku Masyarakat terhadap Bank Syari'ah di Wilayah Jawa Tengah dan Daerah Istimewa Yogyakarta. Jakarta: Bank Indonesia.

Direktorat Penelitian dan Pengaturan Perbankan Bank Indonesia. (2000). Potensi, Preferensi dan Perilaku Masyarakat terhadap Bank Syari'ah di Pulau Jawa. Jakarta: Bank Indonesia.

Karim Business Consulting. (2005). Islamic Banking Consumer Behaviour in Indonesia: A Qualitative Approach. Jakarta: KBC.

Ratnawati, A., \& Mursid, MC. (2011). Potensi dan Strategi Pengembangan Bank Syari'ah di Indonesia: Kajian Produk Syari'ah dari Segi Fiqih Mu'amalat. Jurnal Hukum Islam, 9(2), Desember 2011, 255.

Saeed, A. (1996). Islamic Banking and Interest: A Study of prohibition of Riba and its Contemporary Interpretation. Leiden: EJ Brill

Undang-Undang No. 10 Tahun 1998 tentang Perbankan. 2000. Jakarta: Bank Indonesia. 
Wijaya, A. (2006). Analisis Segmen Pasar dan Perilaku Nasabah Terhadap Bank Syari'ah di Wilayah Yogyakarta dan Implikasi Pemasarannya. Tesis tidak diterbitkan. Bogor: Manajemen dan Bisnis Institut Pertanian Bogor. 